Pompey and Theophanes of Mytilene

Author(s): Barbara K. Gold

Source: The American Journal of Philology, Vol. 106, No. 3 (Autumn, 1985), pp. 312-327

Published by: The Johns Hopkins University Press

Stable URL: http://www.jstor.org/stable/295031

Accessed: 16-06-2015 16:44 UTC

Your use of the JSTOR archive indicates your acceptance of the Terms \& Conditions of Use, available at http://www.jstor.org/page/ info/about/policies/terms.jsp

JSTOR is a not-for-profit service that helps scholars, researchers, and students discover, use, and build upon a wide range of content in a trusted digital archive. We use information technology and tools to increase productivity and facilitate new forms of scholarship. For more information about JSTOR, please contact support@jstor.org. 


\section{POMPEY AND THEOPHANES OF MYTILENE}

Pompey the Great has been closely scrutinized by a variety of biographers in recent years, ${ }^{1}$ but few of these have examined closely his relationships with his clients, particularly the foreign clients. ${ }^{2}$ One of these, Theophanes of Mytilene, is of special interest. ${ }^{3}$ Theophanes was a Greek intellectual who became a friend of Pompey during his campaign in the East in 67 B.C. and remained a part of Pompey's group of friends until Pompey's death. Pompey surrounded himself with a large group of amici who provided a variety of services for him, but Theophanes fulfilled many roles at once: personal historian and chronicler, advisor and confidant, guide to the East. Theophanes was an important enough figure to appear in Cicero's Pro Archia as the archetype of a Greek writer who had received Roman citizenship from a Roman commander. ${ }^{4}$ The Pro Archia, published in 62, soon after Theophanes was granted citizenship by Pompey, defends the franchise of Archias, another Greek who, like Theophanes, had written a book in honor of a commander in

\footnotetext{
${ }^{1}$ The four recent biographies are: J. Leach, Pompey the Great (London 1978); R. Seager, Pompey: A Political Biography (Berkeley 1980); P. Greenhalgh, Pompey: The Roman Alexander (Columbia, Mo. 1981), and Pompey: The Republican Prince (Columbia, Mo. 1982). For other biographies and source books on Pompey, see J. van Ooteghem, Pompée le Grand, bâtisseur d'empire (Brussels 1954); M. Gelzer, Pompeius, 2nd ed. (Munich 1949); Beryl Rawson, The Politics of Friendship: Pompey and Cicero (Sydney 1978). J. P. V. D. Balsdon, in his review of M. Gelzer's Pompeius, points out that any potential biographer of Pompey is challenged by the lack of evidence in the early, and most successful, part of his career and by the mass of conflicting information from different ancient sources (Historia, 1 [1950] 296-300).

${ }^{2}$ There is disagreement regarding the importance of patronage to the fluctuations of Roman politics. See, for example, M. Gwyn Morgan, review of R. Seager (note 1 above) (The History Teacher, 14 [1980/81] 597-98); against this view, see W. S. Anderson, "Pompey, His Friends and the Literature of the First Century B.C.," CPCPh 19 (1963) 34-41.

${ }^{3}$ For Theophanes, see Drumann-Groebe, Geschichte Roms (Berlin 1908) IV, pp. 557-59; R. Laqueur, RE 5A.2090-2127 s.v. "Theophanes."

${ }^{4}$ Cic. Arch. 24. For discussions of the year and place of the grant of citizenship of Theophanes, see L. Robert, "Théophane de Mytilène à Constantinople," CRAI (1969) 47, who says that it was received during the campaigns, and $\mathrm{H}$. de la Ville de Mirmont, "Théophane de Mitylène," REG 18 (1905) 166, 168, who believes after Cicero (Arch. 24) and Valerius Maximus (8.14) that Pompey granted the citizenship to Theophanes on Mytilene in 62 B.C.
}

American Journal of Philology 106 (1985) 312327 (C) 1985 by The Johns Hopkins University Press 
the Mithridatic war. ${ }^{5}$ When Cicero wishes to compliment Pompey in his speech for Archias, he does so by recalling the generous grant of citizenship to Theophanes, "scriptorem rerum suarum [Pompeii] in contione militum" ( $A r c h$. 24). The name of Theophanes, then, was already familiar to Cicero's Roman readers, and his influence with Pompey continued to grow.

I would like in this paper to reopen the question of the importance of foreign clients to Roman imperatores and, within that framework, to assess the significance of Theophanes as a writer of history, a prominent citizen of Mytilene, and a client of Pompey. To this end I will begin with brief remarks on the nature of amicitia and the importance of relationships between Romans and Greek intellectuals, and I will then consider the role played by Pompey's close friends and clients, specifically Theophanes. I am not interested in Pompey's role as a literary patron and will not treat it here; it has been amply treated by others and given far more weight than it, in fact, deserves.

Friendship in Rome, amicitia, was, as Robin Seager says, a "kaleidoscope of sentiments, ranging from simple and sincere affection to urbane and opportunistic hypocrisy," which played a vital part in the social and political life of the Republic. ${ }^{6}$ It was often measured not by affection and loyalty, but rather in terms of political alliances and of beneficia conferred and officia performed. The resulting political union was formed on the basis of reciprocity and mutual interest. ${ }^{7}$ Each party was able to perform a particular favor for the other. When the relationship had outlived its usefulness, it was often dissolved and the members formed new friendships. There was nothing in Rome that remotely resembled our political parties, enduring groups based not so much on the desires of individual men as on long-standing principles.

${ }^{5}$ Archias' work was written in honor of Lucullus. For the connection between Archias and Theophanes, see H. Gotoff, Cicero's Elegant Style: An Analysis of the Pro Archia (Urbana 1979) 191-93; S. P. Haley, "Archias, Theophanes, and Cicero: The Politics of the Pro Archia," CB 59 (1983) 1-4.

${ }^{6}$ See R. Seager, "Amicitia in Tacitus and Juvenal," AJAH 2 (1977) 40.

${ }^{7}$ For a discussion of the terms amicus and amicitia, see E. Badian, Foreign Clientelae (264-70 B.C.) (Oxford 1958) esp. pp. 12-13; P. A. Brunt, "Amicitia in the Late Roman Republic," PCPhS 191 n.s. 11 (1965) 1-20; J. Hellegouarc'h, Le vocabulaire latin des relations et des partis politiques sous la république (Paris 1963) 41-62 and passim; Lily Ross Taylor, Party Politics in the Age of Caesar (Berkeley 1949; repr. 1975) 7-8 and passim; and P. White, "Amicitia and the Profession of Poetry in Early Imperial Rome," JRS 68 (1978) 74-92. 
Lily Ross Taylor calls amicitia the Roman substitute for a political party ${ }^{8}$ this is true only in the sense that amici worked together for a time to achieve a political goal that suited both of their desires. Sallust's famous definition of these fluid Roman political relationships makes clear their ephemeral nature: "sed haec inter bonos amicitia, inter malos factio est." 9

A second type of relationship that existed in Rome in the first century B.C. was the partnership between a foreigner and a Roman, often called hospitium. As is the case with other types of clientela, including amicitia, hospitium had no legal but only a political and moral basis and was constantly redefined. ${ }^{10}$ Like amicitia, it was based on the idea of reciprocity. It was generally not, however, a relationship between men of equal stature, particularly in the late Republic when the Romans held increasing dominance over the rest of the ancient world. Earlier, hospites had been individuals of equal stature, one Roman and one non-Roman, who were obligated to provide hospitality for each other. ${ }^{11}$ By Pompey's time, Roman ascendancy in the ancient world changed the nature of such relationships and gave the Roman partner the superior position. This was particularly true of a Roman imperator like Pompey.

Even at this stage the notion of reciprocity remains the basis for any kind of clientela. All beneficia bestowed were expected to be repaid with suitable officia. Such gifts and favors were not legislated, but their nature was generally understood by both partners. Occasionally we find that foreign clients did not understand their obligations in such relationships; Polybius gives several examples of $\phi ı \lambda$ ía or clientela that

${ }^{8}$ Cf. Taylor (note 7 above); Ronald Syme, The Roman Revolution (Oxford 1939) 157; see also, on the subject of political alliance and morality, D. C. Earl, The Moral and Political Tradition of Rome (Ithaca 1967) ch. I, esp. p. 26.

${ }^{9}$ Sall. BJ 31.15. For a discussion of different kinds of amicitia, see Brunt (note 7 above) 1, 6-7, 20 and passim. Cf. Cic. Amic. passim for descriptions of different types of amicitia, including personal friendships based on mutual affection and shared principles, and Petr. 80.4: sacramentum amicitiae, another reference to private, not political friendship.

${ }^{10}$ Badian (note 7 above) 11-13.

${ }^{11}$ Hospes could also refer to someone who entertained visiting state envoys and in return enjoyed the right of publicum hospitium. See CIL I'2.2.23, 828, 1764; M. Gelzer, The Roman Nobility, trans. Robin Seager (Oxford 1969) 67, 89 ff.; A. von Premerstein, "Vom Werden und Wesen des Prinzipats," $A B A W$ N. F., Heft 15 (1937) 13 f.; Badian (note 7 above) $154 \mathrm{ff}$. See also L. J. Bolchazy, Hospitality in Early Rome: Livy's Concept of Its Humanizing Force (Chicago 1977), who discusses the ius hospitii in Chapter 2. 
failed because the client received favors without returning them. ${ }^{12}$ Polybius himself certainly understood the system and the importance of clientela if his remark to the younger Scipio (quoted by Plutarch) can be trusted: "Never return from the forum until you have made a new friend ( $\phi$ í̀ov) of one of your fellow citizens." 13

Despite evidence that certain foreign dependents did not under-

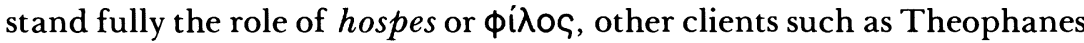
formed lasting bonds with important Romans, performed valuable services for them, and became themselves established members of Roman society. As we shall find in the case of Theophanes, often it was the foreign dependents who became powerful influences on Roman generals and dynasts, sometimes more powerful than Roman amici, because the foreign clients were not so quick to abandon the relationships and, in fact, used them to their own advantage to gain an influential position.

Pompey is famous for his numerous alliances with a variety of Romans and non-Romans: Roman nobility, equites, municipal dynasts, military men, provincials, foreign hospites. He is often painted as a man who searched for a following among foreigners, soldiers, and provincials because the Roman aristocracy scorned him. ${ }^{14}$ It is certainly true that he, like other Romans in his position, relied heavily on ties of amicitia and hospitium for his support, and that he had a larger following than many of his peers. There was every reason for Pompey to seek support from those outside of the traditional aristocratic families. Although technically a nobilis by virtue of his father's consulship in 89

${ }^{12}$ See on this Badian (note 7 above) 45-47; E. Badian, "Notes on Roman Policy in Illyria (230-201 B.C.)," PBSR 20 (1952) 86; S. I. Oost, Roman Policy in Epirus and Acarnania in the Age of the Roman Conquest of Greece (Dallas 1954) 13 and passim; I. E. M. Edlund, "Invisible Bonds: Clients and Patrons through the Eyes of Polybius," Klio 59 (1977) 133-34; A. Mauersberger, Polybios-Lexicon (Berlin 1956) s.v. ảxapıoria. For examples of foreign ingratitude toward Rome, see Polyb. 3.16.2 (Demetrius of Pharus); 3.40.6 (the Boii); see also 15.8.10-12 (Hannibal); 21.31.7 (the Aetolians). Some critics believe that Polybius failed to understand the nuances of the Roman social structure and particularly the possibilities of the system of patronage; see, for example, F. W. Walbank, Polybius (Berkeley 1972) 8. For the opposite view, see Edlund, "Invisible Bonds," $130,135-36$.

${ }^{13}$ Plut. Quaest. Conv. ive656; cf. Comm. Pet. 5.16; L. R. Taylor (note 7 above) 7 ff. See A. Momigliano, Alien Wisdom: The Limits of Hellenization (Cambridge 1975) $24-25$.

${ }^{14}$ For a good discussion of Pompey's bases of power, see E. S. Gruen, The Last Generation of the Roman Republic (Berkeley 1974) 62-66 (=LGRR). 
B.C., he was not from a respected family and was scorned for this reason. ${ }^{15} \mathrm{He}$ had in his background a despised father and lawless and violent beginnings, which had earned him the epithet adulescentulus carnifex. He had usurped the honors of many of the optimates, thus earning their envy and hatred. His name Magnus, acquired during the Sullan civil war, only served as a reminder of his previous misdeeds and incursions on senatorial privilege. ${ }^{16}$

He was not, however, without support from among the nobiles. He developed ties to several leading families through marital alliances. Of five well-planned marriages, two ended in divorce and two in death. His fifth wife, Cornelia, daughter of Q. Metellus Scipio, a man of illustrious lineage but dubious morals, is called by Lily Ross Taylor "the great catch of Rome"; she gave to Pompey closer ties to the optimates and restored his lost prestige. ${ }^{17}$ Each marriage alliance was beneficial to Pompey for a time. The list of his noble adherents in the 70s and 60s is long; it includes men such as P. Servilius Vatia, C. Scribonius Curio, and C. Cassius Longinus, all consulars who gave their support to Pompey's eastern command, and L. Gellius Poplicola and Cn. Lentulus Clodianus, consuls in 72 B.C., who accepted the position of legate with Pompey in his war against the pirates. ${ }^{18}$ But he was rebuffed by Cato when he attempted to marry Cato's niece, ${ }^{19}$ and there was growing suspicion and fear of him in the senatorial circles. In order to cover himself on all sides, he also cultivated friends among the non-nobiles, some of whom served him in a military or political capacity: L. Afranius, T. Labienus, A. Gabinius, and M. Petreius.

Pompey had, then, a large group of adherents from all sectors of society. This enabled him to maintain prestige and power, but the associations fluctuated as did most Roman political relationships, particularly those conducted at higher levels. Fortunately, he was also aided by a smaller and more stable group of men, who became his political advi.

${ }^{15}$ On Pompey's family and status, see G. V. Sumner, "The Pompeii in Their Families," AJAH 2 (1977) 8-25, esp. 16-25. Cf. L. R. Taylor (note 7 above) 121; Syme (note 8 above) 30; F. Münzer, Römische Adelsparteien und Adelsfamilien (Stuttgart 1920) 248 f.; Cic. Verr. 2.5.181 (for Pompey's ancestor).

${ }^{16}$ See Balsdon (review cit. note 1 above) 299 on the name Magnus and its Sullan associations.

${ }^{17}$ For Cornelia, see L. R. Taylor (note 7 above) 35; see Luc. BC 8.73; Münzer (note 15 above) 314 ff. For Q. Metellus Scipio, see Plut. Pomp. 55.1; Cic. Brut. 212 f.; Val Max. 9.1.8; Caes. $B C$ 1.4.3, 3.31.1.

${ }^{18}$ For a longer list, see Gruen (note 14 above) 63; Seager (note 1 above) $36 \mathrm{ff}$.

${ }^{19}$ Plut. Pomp. 44; Cato 30.2-5, 45.1-2. 
sors and publicists and who remained remarkably faithful to him throughout his jagged career. In return for their long and valuable friendship and advice, they obtained a level of influence rarely seen among adherents of Roman magnates. ${ }^{20}$

The group appears a hodgepodge of a most unlikely sort. It included such men as L. Lucceius, L. Scribonius Libo, M. Terentius Varro, and Theophanes. They were indeed from widely disparate backgrounds and are bound together only by their level of influence with Pompey. Lucceius was a wealthy Roman senator who first embarked on an unsuccessful political career and then, after this failed, became a historian of some repute and a personal advisor to Pompey. ${ }^{21} \mathrm{He}$ supported Pompey from the early 60s, opposing Cato and Caesar in their attempts to prosecute those who had profited from Sulla's proscriptions (as Pompey had) and attacking Catiline. Lucceius supported Cicero in 63 , but by 59 had turned against him, presumably in accordance with Pompey's desires. In every political action, he appears on Pompey's side. He turned in the 50s to the writing of history, and was engaged in a history of the Social and Civil wars (which included, quite possibly, Pompey's role in the activities of this period). Cicero, in a famous letter to Lucceius from 56 ( Fam. 5.12) tried shamelessly to win Lucceius over and sign him on as his propagandist, but Lucceius failed to accomplish this task as so many others had. It is from Cicero that we hear of Lucceius' role as advisor to Pompey in the last part of Pompey's life. In two letters to Atticus, Cicero mentions Lucceius and Theophanes as the two men most responsible for advising Pompey to leave Italy in March of 49 and go to Dyrrhachium. ${ }^{22}$ They advised a blockade of Italy using the resources of the East - reasonable advice; the plan, however, failed because Pompey was unable to gain control of the grain-producing provinces and coastal routes.

L. Scribonius Libo, like Lucceius from a nonpatrician but senatorial family, was consul in $34 .^{23}$ He too was a writer of history, but his

\footnotetext{
${ }^{20}$ See Cic. Att. 2.5.1, 2.17.3, 5.11.3; Arch. 24; cf. Caes. BC 3.18.3; Strabo 13.2.3; Plut. Pomp. 76.

${ }^{21}$ For Lucceius, see Cic. Fam. 5.12-15; H. Peter, HRR II.xxx-xxxi (no fragments); H. Bardon, La littérature latine inconnue (Paris 1952) I, $263 \mathrm{ff}$.

${ }^{22}$ Cic. Att. 9.1.3, 9.11.3, where Cicero refers to the inflammatory language of Lucceius and Theophanes.

${ }^{23}$ For Libo, see F. Münzer, RE 2A, 881-85 s.v. "L. Scribonius Libo"; Caes. $B C$ 1.26.3, 3.5.3, 3.18.3, 3.23.2. For Libo's literary activity, see Bardon (note 21 above) I, 268; Cic. Att. 13.30.3, 13.32.3.
} 
main connection to Pompey was adfinitas through his daughter's marriage to Sextus Pompeius in about 55 B.c. He supported Pompey's quest for the commission to restore Ptolemy Auletes to the throne of Egypt in 56, and he was Pompey's must trusted admiral and commander of his fleet (succeeding Bibulus) in 49-48. Libo's appointment as commander-in-chief came at a time in 48 when more and more members of Pompey's family were assuming positions of importance - for example, Pompey's son Gnaeus and his father-in-law Scipio. Libo remained a trusted advisor to Pompey until the end, and even after the battle of Pharsalus worked for the Pompeian cause as a negotiator between his son-in-law Sextus Pompeius and Antony. ${ }^{24}$ In the end, he deserted the Pompeian side and became consul in 34 with Antony; the point is that he was faithful to Pompey and his cause up to and after Pompey's demise.

The third and most prolific member of Pompey's trusted advisory group was M. Terentius Varro. ${ }^{25}$ Varro, a non-nobilis and perhaps a man of wealth, was a legate with Pompey in Spain from 76 to 71, in the East in 67, and again in Spain in 49. He, like the others mentioned above, remained loyal to Pompey throughout his various magistracies and campaigns. He was unlike them, however, in his polymathy and tremendous literary output, some of it designed to praise or to assist Pompey. We know that he produced in 77 a work on naval matters addressed to Pompey; again in 70, this time at Pompey's own request, he

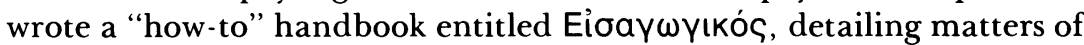
senatorial protocol and procedure for the new consul $;{ }^{26}$ later he published a work entitled De Pompeio. He traveled with Pompey as perhaps a sort of scholar-in-residence, amassing information on such matters as Indian trade routes. ${ }^{27}$ Cicero makes it clear that Varro was an important advisor to Pompey; he acted as a conduit of information for Cicero, Atticus, and Pompey, and it is to Varro, among others, that Cicero appeals for recall in $58 .{ }^{28}$

It was these men, along with Theophanes, who remained faithful

${ }^{24}$ App. $B C 5.52$.

${ }^{25}$ For Varro, see H. Dahlmann, RE supp. 6, 1172-1277 s.v. "M. Terentius Varro"; Aul. Gell. 14.7.2 f. (on Varro's handbook of protocol for Pompey); App. BC 2.9 (on Varro's Tricaranus); Cic. Fam. 11.10.5 (on his wealth if this is the same Varro); Cic. Att. 3.8.3, 5.11.3; Pliny $N H 6.51-52 ; 7.115,16.7$ (on Varro's military and literary achievements).

${ }^{26}$ See on this liber commentarius Aul. Gell. 14.7.2 f.

${ }^{27}$ Pliny NH 6.51-52.

${ }^{28}$ Cic. Att. 3.8.3, 5.11.3. 
to Pompey until the end of his career and had considerable influence on him. Other associations like Pompey's friendship with Metellus Nepos fell victim to the ever-shifting and unreliable political tide and vanished in time. Lucceius, Libo, Varro, and Theophanes, however, remained Pompey's closest advisors, due perhaps partly to their literary abilities, ${ }^{29}$ but also to their long-standing loyalty, which made them valuable allies. As different as they were in backgrounds, abilities, and connections to Pompey, they had one thing in common: all, as Cicero and others make clear, had equal auctoritas with Pompey and helped him to make his most important decisions up until the end. ${ }^{30}$

Theophanes was the only prominent Greek in this group. ${ }^{31} \mathrm{He}$ had taken a leading role in opposing Mithridates on Lesbos in the 80s B.C. Mytilene had, at that time, lost her freedom because of her stiff opposition to the Romans. Pompey the Great moved into the East against the pirates in 67 в.C. under the powers granted to him by the Lex Gabinia, and it is reasonable to assume that he met Theophanes when he was using Mytilene as a naval base. Theophanes was certainly in the company of Pompey the next year when Pompey's command was extended to include the war against Mithridates. He was, Strabo tells us, both a

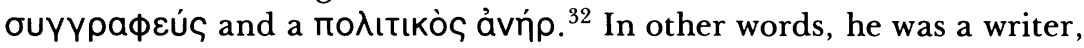

${ }^{29}$ Pompey may also have adopted some of these men as amici out of literary interests. On the question of Pompey's intellectual interests or lack of them, see the essay by M. H. Crawford, "Greek Intellectuals and the Roman Aristocracy in the First Century B.C." in P. D. A. Garnsey and C. R. Whittaker, eds., Imperialism in the Ancient World (Cambridge 1978) 193-207, in which it is argued that Pompey and other Roman principes were philistines and were interested in Greek intellectuals only for their snob appeal, and that the Greeks in turn fostered the illusion of these Roman magnates as men "of deep Hellenic culture" (p. 204). A. N. Sherwin-White in his review of the book disagrees ( TLS [April 18, 1980] 447).

${ }^{30}$ See note 20.

${ }^{31}$ There were other Greeks besides Theophanes in Pompey's circle of friends, but none as prominent or faithful as Theophanes. Among those who might be mentioned are Curtius Nicias of Cos, scholarly and urbane, who attached himself to many prominent (but often unsavory) Romans: Pompey, Memmius, and Dolabella. Syme suggests that he may have come to Rome in 62 with Pompey from the East along with Theophanes (see R. Syme, "Who was Vedius Pollio?" JRS 51 [1961] 25-26, 27-28; Suet. Gram. 14). Another Greek in Pompey's house was Demetrius of Gadara, a freedman of great wealth and influence (see Syme [note 8 above] 385). He was, like Theophanes, honored by Pompey through a gift to his native city (Gadara); see Plut. Pomp. 40; Jos. BJ 1.155; AJ $14.74 \mathrm{f}$.

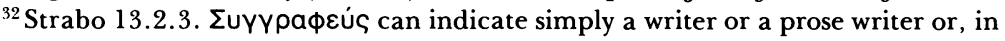
a more restricted meaning, one who collects and writes down historical facts, a historian. Cf. LSJ v. бuүүрафєúc; Plato Phaed. 272b; Isoc. 15.35; Xen. Hell. 7.2.1; Dion. Hal. Thuc. 5. 
but, perhaps more important to Pompey, he was a man who was involved in the political life of Mytilene and who could thus be of help in Pompey's reorganization of the East. He was one of a group of cultured Greeks and Easterners who accompanied Roman imperatores on their campaigns and acted as guides to an unfamiliar world, advisors, and sometimes chroniclers or panegyrists. ${ }^{33}$ Theophanes went along with Pompey on his Eastern expeditions against the pirates and, Strabo says, "became a friend to Pompey, particularly on account of his integrity

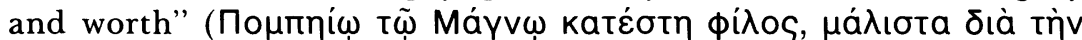

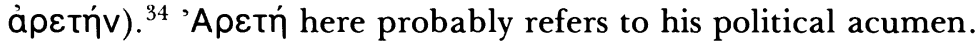

It is clear that Theophanes was a man well-versed in the political affairs of his own city and also knowledgeable about the geography of the region; thus, he was able to act as an advisor and guide for Pompey. Strabo tells us that Theophanes "set straight all of Pompey's affairs for

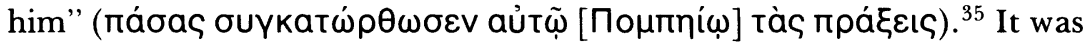
important for the Romans in this period to have a good knowledge of Greek affairs, language, customs, and topography. ${ }^{36}$ This knowledge gave the Romans a real edge over the Greeks, who knew nothing about the local area and customs. ${ }^{37}$ Pompey could have gained much useful information about the customs, attitudes, and terrain of the Greek East from Theophanes, and among the services that Theophanes performed for Pompey, the most valuable were undoubtedly paving the way for him at Mytilene, which Pompey was later to use as a base of operations, and instructing him in the habits and customs of the area. ${ }^{38}$

Theophanes also performed another service for Pompey: a work written in honor of him. Jacoby cites seven extant fragments or para-

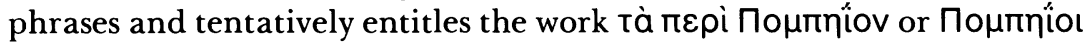

${ }^{33}$ For examples of other men like Theophanes, see G. W. Bowersock, Augustus and the Greek World (Oxford 1965) 2-4.

${ }^{34}$ Strabo (13.2.3). (ảpetñv here is an emendation for the manuscript reading aùinv.) $\phi i \lambda \circ \varsigma$ in this passage carries no doubt the same ambiguity as the latin amicus and means "friend" in both senses: a personal friend and political ally.

${ }^{35}$ For other uses of the rare word ouykatop日oũv, "to help succeed," cf. Isoc. Phil. 5.151; Dion. Hal. 6.86.2 (cf. દ̇navopӨoũv, Dion. Hal. 6.86.5).

${ }^{36}$ See Momigliano (note 13 above) 36-40; Bowersock (note 33 above) 3-4, 30-31.

${ }^{37}$ See Polyb. 31.25.4, 39.1; Momigliano (note 13 above) 38. Not all Romans knew Greek well, however; see Nicholas Horsfall's article on the subject called "Doctus Sermones Utriusque Linguae?," CNV 23 (1979) 79-95.

${ }^{38}$ For Theophanes and Pompey at Mytilene, see Gelzer (note 1 above) 84 and 272, n. 65 . 


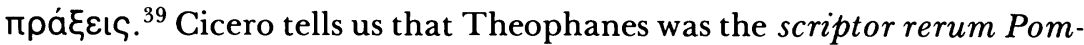
peii and implies that Theophanes was awarded Roman citizenship by Pompey as a result of this work. ${ }^{40}$ The work must have been written by 62, since Cicero mentions it in the Pro Archia. Theophanes may have been rewarded at least partly for acting as guide and advisor to Pompey in the East and not only for his work in honor of Pompey; we must keep in mind here that Cicero is simply using Theophanes, the writer, as an example to support his defense of Archias' enfranchisement.

Both Cicero and Plutarch inadvertently reveal some interesting facts about Theophanes' relationship to Pompey. Cicero, in the many letters to Atticus in which he mentions Theophanes, makes it very clear that he relied on Theophanes to act as a liaison between himself and Pompey, and that he viewed Theophanes as a man of influence with Pompey. Cicero sees Theophanes as someone who is fully apprised of both the political situation in Rome and of Pompey's views. ${ }^{41}$ He tries to convince Pompey not to go to Spain by asking Theophanes to "apply pressure to" (incumbet) Pompey, and he ends his letter with this comment: "valet autem auctoritas eius apud illum (Pompeium) plurimum." 42

Plutarch relates two anecdotes about Theophanes in his capacity as a writer and propagandist for Pompey. ${ }^{43}$ One concerns notebooks belonging to Mithridates found in a fort of Mithridates that was surrendered to Pompey. These notebooks, Plutarch says, not surprisingly were of considerable interest both to Pompey and to Theophanes. Also found in this fort was a speech of Rutilius Rufus, who was at that time living as an embittered exile in the East. In this speech, Plutarch claims, Rutilius Rufus urged Mithridates to massacre all Romans living in Asia. Plutarch says that most people believe that the speech was a malicious invention of Theophanes designed to please Pompey by implicating Rutilius Rufus, who was a former enemy of Pompey's father. ${ }^{44}$ The second

${ }^{39}$ Jacoby, FGrHist iiB.188.

${ }^{40} \mathrm{Cic}$. Arch. 24. This is the earliest mention of Theophanes (62 B.C.).

${ }^{41}$ Cic. Att. 2.5.1, 2.12.2, 2.17.3.

${ }^{42}$ Cic. Att. 5.11.3.

${ }^{43}$ Plut. Pomp. 37, 49.

${ }^{44}$ Plutarch seems to believe that Theophanes wrote the speech and inserted it himself into the papers of Mithridates. It is also possible that Theophanes only alleged this speech was found. See Anderson (note 2 above) 36; de la Ville de Mirmont (note 4 above) 180-83, 192,194, who points out that Plutarch may have borrowed this story from the sharp-tongued Timagenes, who was always ready to vilify Theophanes. 
anecdote, which Plutarch attributes to Timagenes, concerns Ptolemy Auletes, who had left Egypt and wished to be restored to the throne. Timagenes claimed that Theophanes had been responsible for persuading Ptolemy to leave Egypt in order to create a new command for Pompey. It is interesting to note that, whether or not either of these was true, Plutarch even thought it plausible for Theophanes to have done such things merely to please Pompey.

What did Theophanes receive from Pompey in return for his services? What could a Greek client expect from a Roman of Pompey's stature? Theophanes, Cicero tells us, was made a citizen by Pompey, an act that was vociferously approved by the Roman soldiery present at the public ceremony (Arch. 24). He was also appointed praefectus fabrum. ${ }^{45}$ This was an important post, not to be underrated, and held by many an interesting man. In this period (the later republic), the praefectus fabrum was, in essence, a chief-of-staff to a person holding the high command. It was given to such men as Volumnius Eutrapelus, praefectus fabrum of Antony in 43; Mamurra, much reviled by Catullus, ex-Pompeian and praefectus fabrum of Caesar in Gaul in 58-55; and Cornelius Balbus, praefectus fabrum of Caesar in Spain and the most intriguing of the group, partly because of the close parallels between him and Theophanes. ${ }^{46}$

We should, perhaps, examine him more closely. L. Cornelius Balbus, like Theophanes, began as a very prominent citizen of his own city, Gades, and obtained citizenship through Pompey's offices, probably from L. Cornelius Lentulus Crus, for services during the Sertorian War. ${ }^{47}$ Balbus later became associated with Caesar and was made his praefectus fabrum not once but twice, both when Caesar was praetor and when he was consul. ${ }^{48}$ Because of Balbus' importance to Caesar, Caesar gave many favors to the citizens of his native city, Gades, as Pompey did to Theophanes' city, Mytilene (Balb. 43). Balbus remained an extremely influential man with Caesar and in Roman life as a whole.

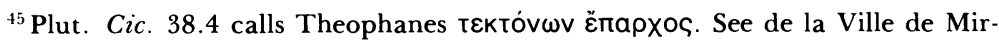
mont (note 4 above) 197-99, who places much importance on this post. J. Suolahti, however, in a book entitled The Junior Officers of the Roman Army in the Republican Period. A Study on Social Structure (Helsinki 1955), describes the praefectus fabrum as the equivalent of an aide-de-camp, whose importance depended on the status of his commander. He points out that men such as Balbus used the post to rise to a high position in government (pp. 205-9, 216).

${ }^{46}$ See Syme (note 8 above) 355 and $\mathrm{n} .2$ for other possible praefecti fabrum.

${ }^{47}$ For Balbus and Lentulus, see Cic. Att. 8.15A.2, 9.7B.2.

${ }^{48}$ The years were probably $62-59$ B.C.; see Cic. Balb. 63 . 
Like Theophanes, Balbus remained loyal to his patron up until and even after his patron's death. ${ }^{49}$

Another parallel between the two men lies in the lasting mark they left on Roman society. Theophanes found a firm foothold in Rome: his son, Pompeius Macer, was a knight and procurator of Asia under Augustus, and his grandson rose to the post of praetor in A.D. $15 .^{50}$ So too, Cornelius Balbus, who himself rose to be consul suffectus in 40 B.C. as an adherent of Octavian and had a nephew, L. Cornelius Balbus Minor, who became quaestor in Spain under Pollio in 44 B.C. Much of his family was enfranchised: father, brother, and nephew, and Balbus Minor became consul suffectus in $32 .{ }^{51}$ Balbus, like Theophanes, became a sort of ambassador for his own city; Cicero calls him a hospes in the Pro Balbo (43). We have little evidence, however, that Theophanes became unpopular with the Roman nobiles (except possibly Cicero's remark to Atticus in Att. 9.11.3), whereas Balbus' weighty influence over both Pompey and Caesar, his wealth, and his extravagance caused him to become persona non grata in high circles (Balb. 18.56-59). Eventually, in 56, his citizenship was called into question 16 years after his enfranchisement, by a fellow-townsman from Gades, who was spurred on, no doubt, by political elements in Rome. ${ }^{52}$ Cicero successfully defended Balbus' case.

One last and rather strange incident links the two influential foreign clients. In 62 , Balbus was adopted by Theophanes, a situation mentioned by Cicero in the Pro Balbo as something much discussed and criticized by many, but perfectly defensible (Balb. 57). Later, however, in a letter to Atticus in 50, Cicero lists this as just one more bizarre irregularity that he was forced to tolerate along with Caesar's command, the adoption of a patrician by a plebeian, and the wealth of Mamurra and Balbus. ${ }^{53}$ Cicero explains this adoption in a vague way, saying only that

${ }^{49}$ See, e.g., Suet. Div. Iul. 53, 81.2.

${ }^{50}$ Tac. Ann. 1.72, 6.18; ILS 9349; G. W. Bowersock, "Eurycles of Sparta," JRS 51 (1961) 116-17, n. 42. R. Syme, Tacitus (Oxford 1958) 748-49, discusses the problem of how many generations there were between Theophanes and the praetor of A.D. 15; there is some confusion on this point. Theophanes himself was still active in Roman affairs after Pompey's death; see Cic. Att. 15.19.1.

${ }^{51}$ Cic. Fam. 10.32 (a letter from Pollio to Cicero castigating the younger Balbus); Pliny NH 5.36, 7.136; CIL 1, p. 168 (for citizenship).

${ }^{52}$ The situation of Balbus is closely parallel to that of Archias, whose claim to citizenship Cicero also defended. Both men had held the citizenship for many years by the time they were brought into court for what were obviously political reasons.

${ }^{53}$ Cic. Att. 7.7.6. 
through it Balbus gained an inheritance from his relatives. In any case, the adoption must have taken place shortly after Theophanes came to Rome with Pompey in 62, and Balbus went so far as to call himself Balbus Theophanes. ${ }^{54}$ One is tempted to think that Pompey must have figured largely in this adoption since he was then the patron of Theophanes and had been the patron of Balbus, or that the purpose of the adoption was to forge another link between Pompey and Caesar through their praefecti fabrum. We might compare the alliance made in 59 , only a couple of years later, by the marriage of Julia to Pompey. It is unlikely that Theophanes needed an heir; his son may well have already been born by then $\left(P I R^{1} \mathrm{P} 472\right)$.

A further favor that Theophanes, like Balbus, received for which we have considerable epigraphical evidence were the benefits done for his city of Mytilene by Pompey. After his campaign against Mithridates, Pompey returned with Theophanes to Mytilene, viewed a festival in his own honor, and restored to Mytilene the freedom that she had lost in 79 B.C. ${ }^{55}$ For this important service to his fatherland, Theophanes was rewarded with inscriptions honoring him as benefactor, savior, and second founder of the city and, ultimately, probably after his death, with deification. The earliest inscription honoring Theophanes, dating perhaps from about the time when Theophanes received Roman citizenship from Pompey, has only recently come to light, not on Lesbos but in Constantinople. ${ }^{56}$ This inscription has been published and examined in detail by Louis Robert. It is on a statue base and is in an Aeolic dialect; Robert speculates that this once supported a statue of Theophanes and was brought at a later date to the hippodrome at Byzantium. The inscription honors Theophanes, called Gnaeus Pompeius Theophanes, for having recovered from the Romans, the universal benefactors, their city, territory, and freedom, and for having caused to be reestablished the ancestral cults and rituals. Theophanes is honored for his ảpetń and

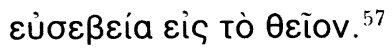

${ }^{54}$ See Laqueur, RE 5A.2099.21.

5.5 Plut. Pomp. 42.43.3. Plutarch claims that Pompey was inspired by the theater at Mytilene where the games were held to build his theater at Rome. The Roman theater, however, is built on traditional Italian lines, and it is difficult to see a Greek model for it. See J. A. Hanson, Roman Theater-Temples (Princeton 1959) 43 ff.; Anderson (note 2 above) 35 .

${ }^{56} \mathrm{~L}$. Robert (note 4 above) 42-64, esp. $52 \mathrm{ff}$.

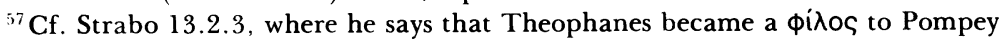
because of his ảpetn். 
Other inscriptions also indicate the importance of Theophanes as an outstanding citizen of Mytilene and the gratitude owed to him by the

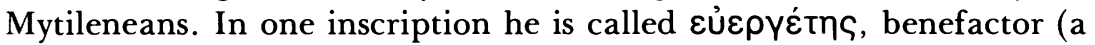
title given to the Romans in the Constantinople inscription) and $\sigma \omega t \eta \dot{\rho}$ (savior), neither of which, as Robert points out, is a religious title ${ }^{58}$ But elsewhere, in a tripartite inscription dedicated to Pompey, Theophanes and another illustrious Mytilenean of the Augustan age, Polemon, Theophanes is deified. ${ }^{59}$ This may have given rise to Tacitus' charge of Graeca adulatio for those who had given Theophanes caelestis honores. ${ }^{60}$ Theophanes holds the central place of honor in this inscrip-

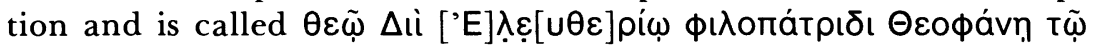

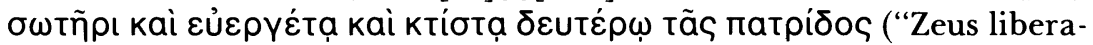
tor, friend of his native city, Theophanes, savior and benefactor and second founder of his city"). Some have speculated that the two parts of the inscription dedicated to Pompey and Theophanes were inscribed early, in the 60s, and the section to Polemon later, but Robert makes a strong case for the view that the entire inscription was dedicated under Augustus or sometime after Theophanes' death. If Robert is correct, then Theophanes was deified only posthumously by his fellow citizens, perhaps to ensure the continuation of his benefactions even after death. ${ }^{61}$

The epigraphical evidence is essential to demonstrate the importance of Theophanes both in his own right as a citizen of Mytilene and as an associate of Pompey. His fame and reputation as the liberator of Mytilene (and thus the title of "second founder") long survived him.

The relationship of this Roman imperator and his Greek friend and advisor closes on a rather ironic note. After the battle of Pharsalus, when Pompey was deliberating with his closest advisors over the safest place of refuge, three possibilities were suggested: Parthia, Africa, and Egypt. ${ }^{62}$ Our information for this episode comes mainly from two con-

${ }^{58} I G$ 12.2.150; IGR 4.56; Dittenberger, Sylloge ${ }^{3}$ 755. E. Fabricius, "Inschriften aus Lesbos," MDAI 9 (1884) 86, n. 2; Robert (note 4 above) 48-52.

${ }^{59} I G$ 12.2.163; IGR 4.55; Dittenberger, Sylloge $e^{3} 752,753,754$.

${ }^{60}$ Tac. Ann. 6.18.

${ }^{61}$ See also Laqueur, RE 5A.2094. We might compare the less kind fate of the aforementioned Nicias of Cos, client of Pompey, Memmius, and Dolabella, who returned to his native island from Rome and was buried there. His fellow citizens, however, violated his tomb. See Anth. Pal. 9.81.

${ }^{62}$ For the various accounts of this episode, see Plut. Pomp. 76; Luc. BC 8.331453; App. BC 2.83. See also Anderson (note 2 above) 38-40. 
flicting accounts in Plutarch and in Lucan. There is no basis for choosing one account over the other, or for believing that either speech is accurately transmitted; nonetheless, the reported speeches bear examination. Plutarch claims that Theophanes alone recommended that Pompey go to Egypt, where he might expect to receive fair treatment from the young Ptolemy whose father he had helped. ${ }^{63}$ According to Plutarch's account, Theophanes also suggested as a second viable alternative that Pompey join Caesar, to whom he had once been related by marriage and who was known for his moderation. Theophanes thought, according to Plutarch, that to decide against either one of these reasonable choices and for Parthia was madness. ${ }^{64}$ Parthia, Theophanes maintained, was an ignoble and un-Roman choice, because the Parthians were a treacherous race, and also because Pompey might expose his noble wife Cornelia to their wantonness. Plutarch ends by commenting that Pompey, swayed solely by the latter consideration, went to Egypt

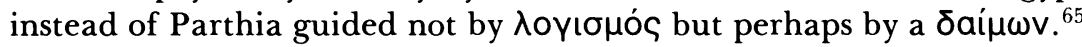

Lucan gives a similar account but, as we might expect from a Roman writer, puts the speech, in greatly amplified form, into the mouth of a Roman, the ex-consul L. Cornelius Lentulus. ${ }^{66}$ Lentulus, like Theophanes in Plutarch's account, claimed that to take refuge with the Parthians would be shameful, un-Roman, and unsafe for the noble Cornelia. Lucan introduces Lentulus' speech by calling it dignas modo consule voces. ${ }^{67}$ The language in the speech of Lucan is of course thoroughly Roman (libertatis amor, 340; vulnus pudoris, 349-50; fiducia, 362 ), but the argument is the same as that which Theophanes advances.

What are we to make of all of this? Plutarch, who may have had Lucan's account, chose to put this speech in the mouth of a Greek. ${ }^{68} \mathrm{He}$ weakens the impact of Theophanes' advice by having Theophanes present his alternatives in a negative fashion, and by stating twice that irrationality was involved in Pompey's final decision. Nonetheless, Theophanes' speech was, by this account, psychologically astute enough action.

${ }^{63}$ App. BC 2.83 claims that all of Pompey's advisors recommended this course of

${ }^{64}$ Plut. Pomp. 76.5.

${ }^{65}$ Plut. Pomp. 76.6.

${ }^{66}$ Luc. $B C 8.331-453$.

${ }^{67}$ Luc. $B C 8.330$.

${ }^{68}$ We do not know whether Plutarch used Lucan as a source or not, but there are many close correspondences, e.g., Luc. $B C 5.406$ ff., esp. 577-93; and Plut. De fort. Rom. 319 C-D. 
to convince Pompey to act against the counsel of all of his other advisors.

If we believe Plutarch, then we must admit a fact that rather clouds the end of this relationship: Theophanes was responsible for the death of Pompey. We have no way of knowing which of his advisors did indeed suggest this ill-omened plan. Plutarch, however, at least thought it possible that Theophanes' advice would have been seriously considered. And that it should be plausible for a man such as Theophanes, a Greek without previous influence in Rome, to have such a relationship with so powerful a Roman as Pompey is an interesting note in the history of such relationships. Their relationship, like that of Libo, Lucceius, and Varro with Pompey, seems to have been founded on a genuine and lasting loyalty and not simply on opportunism. If we can believe Cicero, foreigners like Theophanes and Balbus held extremely important positions with the major Roman leaders of the first century в.C. and were the chief sources of information for those who, like Cicero, tried to ascertain the thoughts and potential movements of these leaders. The clients, in turn, improved their own lot, both in Rome and in their native cities, but also made this amicitia more than the ephemeral and self-seeking relationship that if often was between one Roman and another. ${ }^{69}$

Barbara K. Gold

University of Texas at Austin

${ }^{69} \mathrm{An}$ abbreviated version of this paper was presented at the 1980 meeting of the Classical Association of the Middle West and South in Columbia, S.C. 